
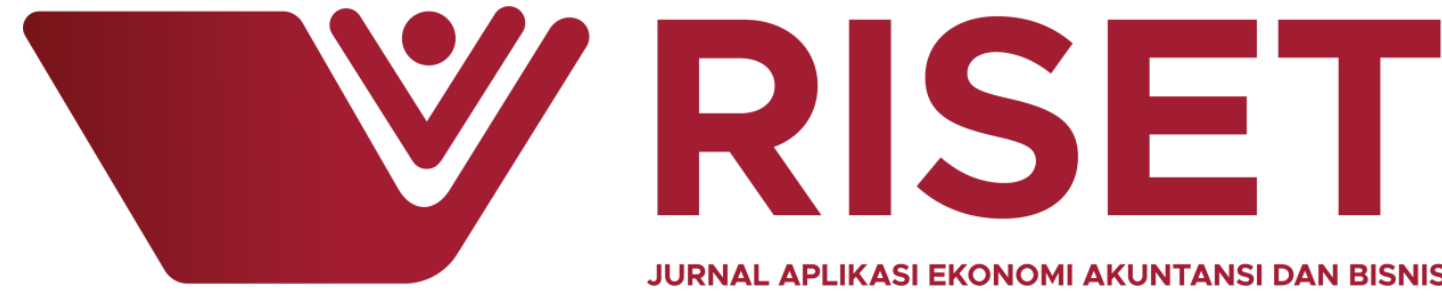

JURNAL APLIKASI EKONOMI AKUNTANSI DAN BISNIS

\title{
RELATIONS GREEN BUSINESS INNOVATION TO KNOWLEDGE, ENTREPRENEURIAL BUSINESS AWARENESS AND AWARENESS OF COCONUT YOUNG (COCOS NUCIFERA LIN) AND ITS IMPACT ON ENVIRONMENTAL SUSTAINABILITY
}

\author{
Bahri ${ }^{1)}$, Ilmardani Rince Ramli ${ }^{2)}$, Widodo Prasetyo ${ }^{3)}$ \\ 1,2),3) Widya Mataram University
}

\begin{abstract}
INFO ARTICLES

Relations Green

Business Innovation

Top Knowledge,

Entrepreneurial

Business Awareness

And Awareness Of

Coconut Young (Cocos

Nucifera Lin) And Its

Impact On

Environmental

Sustainability

Submitted:

09-March - 2020

Revised:

$20-$ May - 2020

Accepted:

25 - September - 2020

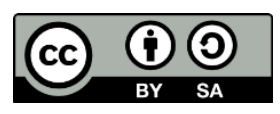

This research was conducted to analyze the direct and indirect relationship between green business innovation dimensions through the Knowledge, awareness, and concern of young coconut entrepreneurs (Cocos nucifera lin). It could be done towards environmental sustainability to minimize greenhouse gas emissions caused by entrepreneurial activities that cause global warming. The number of samples used in this study was 60 respondents with the sampling technique using purposive sampling. The data analysis method used was bivariate correlation analysis and path analysis (path analysis). Result study found a significant positive relationship between green input, green process, green products, green marketing to Knowledge, awareness, and concern. Directly green information, green revolution, green development, green marketing have a positive and significant relationship to environmental sustainability. The variables of Knowledge, awareness, and concern have a positive and meaningful connection to ecological sustainability. From the results of the path analysis, the direct relationship value is greater than the indirect cost. Green, green, green, and green marketing through the variables of knowledge, awareness, and concern do not have an indirect relationship to environmental sustainability.
\end{abstract}

Keywords: Green Business Innovation, Knowledge, Awareness, Concern, Environmental Sustainability.

E-mail: bahri@widyamataram.ac.id $\stackrel{11}{ }$,daniramligallery@gmail.com ${ }^{21}$,widodoprasetyo8710@ gmail.co $\mathrm{m}^{2)}$

\section{INTRODUCTION}

Increased business activity (especially in Indonesia), certainly will air impacts on the environment are getting worse. This is due to the low level of knowledge, awareness, and concern of society towards the ground. According to Azmi (2017), the environmental damage caused by lack of experience, the level of understanding, and respect for the environment entrepreneurs result in damaged ecological life. Aman et al. (2012); Rini et al. (2017) stated that environmental factors that can influence green products' purchase intention are environmental knowledge, ecological awareness, 
ecological concern, and attitudes. The existence of environmental damage minimized by implementing green business innovation. Green business innovation always makes a positive contribution to the environment, organization, consumer, and social community to improve the organization's profitability (Zaraswati, Sumarwan, Vitello, 2017). Furthermore, according to Fitriyah, Tjahjadi, \& Soewarno (2020), green business innovation is a business activity to make input into output by prioritizing balance and synergy between economic, social, and environmental benefits. The concept of green business innovation is initiated from defining the information raw material (green input), processing of raw materials (green process), product or output produced (green product), and the distribution or sale (green marketing). These are not only focused on profit but also pay attention to their social responsibility towards society and environmental sustainability (Utomo and Pratiwi, 2016). Ecological damage caused by mountains of garbage can weigh on the earth and cover the earth's surface (Rahmawati, 2018). Yogyakarta City was chosen as the research site because the waste produced in Yogyakarta is the most massive waste disposed of in landfills. Yogyakarta delivers 900 grams of trash per day to make waste transported to the final disposal (landfill) in 270 tons per- day. From these areas, one of the waste-producing sites, mostly young coconut waste, is Umbulharjo District. In Subdistrict Umbulharjo, the total number of garbage is enormous. Due to this area is not supported by depot garbage availability, every site is due to government constraints to increase the number of polling garbage because the limited land empty and not all citizens willing to be built TPS trash around the neighborhood for causing a stink. With the limited TPS causing accumulation of waste. These also can be seen in the Semaki Depot at Kemuning, Umbulharjo, Yogyakarta, which experienced piles, mostly when the Piyungan TPA was closed.

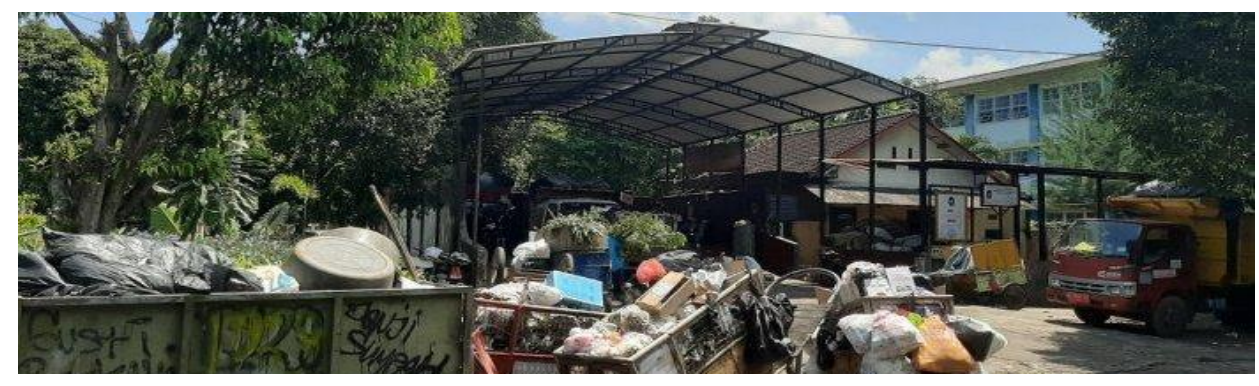

Figure 1. Garbage depot in Umbulharjo District

Government efforts Umbulharjo, Yogyakarta to overcome the accumulation of garbage to execute trash problem, in collaboration with the Department of Environment (DLH) Yogyakarta to sweep, pile up and dispose of waste to landfill Piyungan. A prohibited littering banner is installed, as seen on Lowanu, Sorosutan Village, Umbulharjo District. However, the local community still littered illegally.

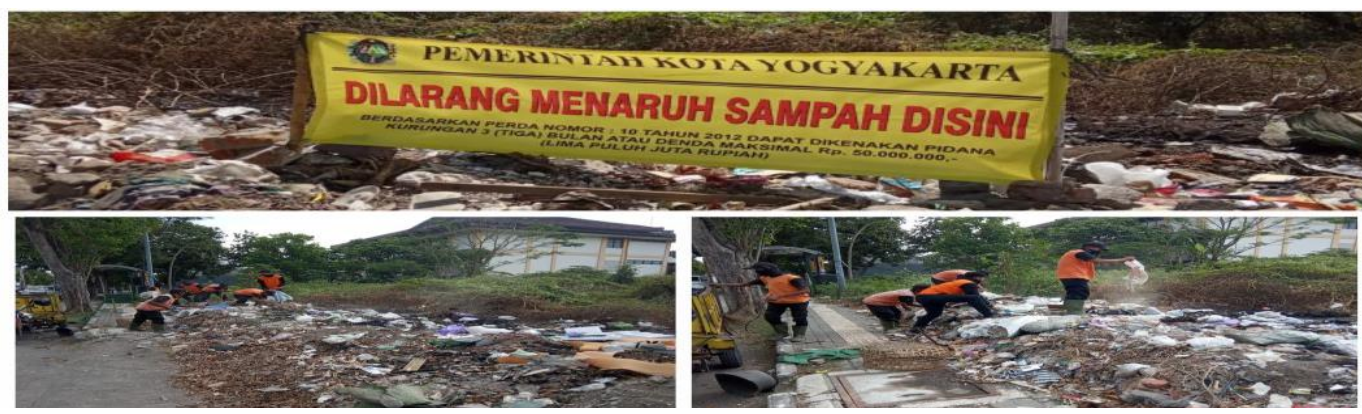

Figure 2. Environmental Dina s Officer's Transporting Garbage 
Of these areas, only one producing room for young coconut waste is Umbulharjo District, Yogyakarta. D ith the limitations of the polling stations and the inability of young coconut entrepreneurs to manage garbage, then the perpetrators of attempts to let garbage pile up just like that showed in the image below :

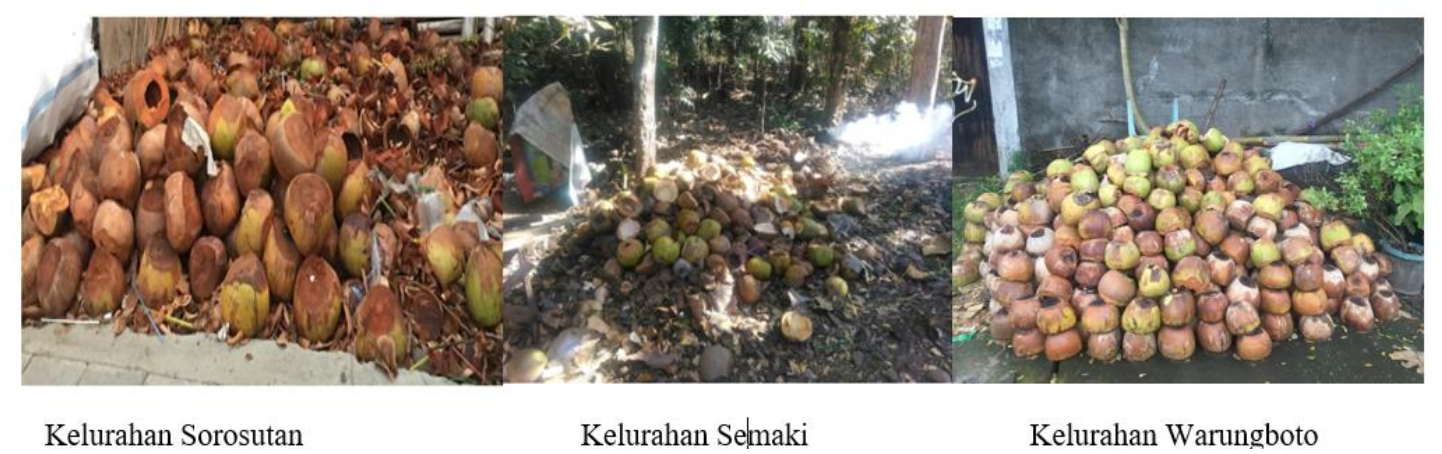

Figure 3. Young Coconut Garbage Stacking

Coconut (Cocos Nucifera) is an agricultural product that has high economic value. However, coconuts can also be a source of problems where the waste from the coconut processing process pollutes the Environment and disturbs the view due to being ignored by traders. The lignin content in young coconut shells makes it not easy to decompose on the ground and has high water content. Young coconut waste piling might cause an odor, which stimulates mosquito breeding. Waste is disposed of and piled up. After drying, the waste is burned. However, in the combustion process, black smoke is also produced, which is harmful to health.

\section{Formulation of the problem}

Based on the discussion above, the problem formulations in this study are:

1. Is there a connection between green business innovation, green input, green process, green products, and green marketing on the level of knowledge, level of awareness, and concern for young coconut entrepreneurs (Cocos Nucifera lin) in Umbulharjo District, Yogyakarta?

2. Is there a relationship between knowledge, awareness, and concern of young coconut entrepreneurs (Cocos nucifera lin) on environmental sustainability in Umbulharjo District, Yogyakarta?

3. Is there a direct and indirect relationship with the dimensions of green business innovation? Which consists of green input, green process, green products, and green marketing towards environmental sustainability in Umbulharjo District \& Yogyakarta through knowledge, awareness, and concern for young coconut entrepreneurs (Cocos nucifera lin)?

\section{Research Objectives}

The objectives of this research are:

1. To determine whether there is a relationship between green business innovation dimensions, which consists of green input, green process, green products, and green marketing on the level of knowledge, awareness, and concern of young coconut entrepreneurs (Cocos nucifera lin).

2. This research is to determine whether there is a relationship between knowledge, awareness, and concern of entrepreneurs (Cocos nucifera lin) on environmental sustainability in Umbulharjo District, Yogyakarta. 
3. The direct and indirect relationship between green business innovation dimensions consists of green input, green process, green products, and green marketing towards environmental sustainability in Umbulharjo District.

4. It is hoped that as input to the Umbulharjo Subdistrict government, Yogyakarta, it is necessary to handle young coconut and other waste that is very disturbing to the environment.

\section{LITERATURE REVIEW}

\section{Green Business Innovation}

In operations, business actors are required to apply the concept of green business innovation, which is expected to produce environmentally friendly products. By using the idea of green business innovations, business actors can participate in preserving the environment for a better future. Green business is a profit-oriented business concept with a vision of protecting the environment in its business activities (Wijayanto, 2017). Aulia and Agustina (2015) stated that green business or green business is a business activity that does not negatively impact the global environment, local communities, and environmental responsibility.

\section{Green Input}

Green input is in making products using environmentally friendly raw materials or conserving energy and resources. Its application can have several positive impacts, including reducing waste, minimizing the use of chemicals, and saving energy. Utomo's research results, Pratiwi (2016), that green input influences MSME players' performance in Tarakan.

\section{Green Process}

The green process is a method used to produce goods using tools or technology. The green process might limit pollution or benefit the environment without endangering society. Furthermore, in Utomo's research results, Pratiwi (2016) also proves that the application of green business processes can improve actors' performance. Meanwhile, Fitriani's research results (2017) that green process innovation influences the product's competitive advantage. Also, the increase of green process innovation can increase the competitive advantage of batik products.

\section{Green Products}

Green products result from company operations that produce products and services using safe and environmentally friendly materials for humans in energy consumption. According to Khasali (2005), green products or green products are an illustration of goods or products produced by producers related to a sense of security and actions that impact human health and do not potentially damage the environment.

\section{Green Marketing}

Green marketing refers to the satisfaction of customer needs, wants, and desires with the maintenance and preservation of the environment; eco-label, eco-brand, and environmental advertisements are part of green marketing (Rahayu, Abdillah, Mawardi, 2017). Furthermore, Rahayu, Abdillah, Mawardi (2017), in their research results, show that there is a significant effect of green making either jointly or partially environmental awareness, green product features, green product prices, and green product marketing on purchasing decisions. At the same time, Situmorang (2012) of green marketing is the 
marketing concept of products using ingredients that do not damage extended circles Ungan life.

\section{Knowledge}

Utami, Gunarsih, Aryanti (2014) describes a series of ecological knowledge possessed by individuals regarding the environment according to facts, concepts, and relationships between the natural environment and the surrounding ecosystem. Meanwhile, according to Research by Rini, Sukaatmadja, Giantari (2017) proves that Knowledge affects people's behavior and purchase intentions.

\section{Awareness}

According to the massive Indonesian dictionary, awareness is the ability to use common sense to digest information and conditions that are happening and experienced. Hasibuan (2012) attention is the attitude of a person who voluntarily obeys all rules and is aware of his duties and responsibilities. Public awareness is realized by the community, taken from habits in society, influenced by the Environment, regulations, and government's role (Muttaqien et al., 2019). Paramita and Yasa (2015) state that environmental awareness is an individual's awareness of a clean and healthy environment such as ecological cleanliness, water use and management, vehicle pollution, and ecological balance stability based on environmental values.

\section{Concern}

The concern comes from the word care (care), which means a fundamental value and a person's attitude to pay attention and act proactively to the conditions or circumstances around him. Caring is a fundamental and essential requirement for survival, success, and a healthy life (Barnes, 2012). According to Yaumi (2014), to care for the environment is an attitude exemplary, aiming to achieve harmony, harmony, and balance between humans and the environment. Creating a human environment with the philosophy and fostering the environment of activities caused pollution, damaging the environment. Rini and Marsudi (2017) explain that environmental concern can be considered attention to facts and behavior from oneself with specific consequences for the environment.

\section{Environmental Sustainability}

Humans are one of the determining factors in preserving the environment, which has a role and responsibility to empower environmental resources for ecosystem life (Karim, 2018 ). Sustainability is a process that made environmental protection from an annihilation perspective education (Hafizah, 2018). Environmental management is an integrated effort to preserve ecological functions, including policies for ecological management, utilization, development, maintenance, restoration, supervision, and control (Taufiq, 2014). The point is that environmental preservation is an act of protecting the environment from extinction (Hafizah, 2018).

\section{Research Hypothesis}

The hypotheses in this study are:

$\mathrm{H}_{1}$ : Suspected green input, process green, green products, and green marketing has a positive and significant relationship to knowledge, awareness, and concern entrepreneurs young coconut (cocos Nucifera lin).

$\mathrm{H}_{2}$ : Allegedly a da relationships strong positive between knowledge, awareness, and concern for environmental sustainability in the Umbulharjo area, Yogyakarta. 
$\mathrm{H}_{3}$ : It is suspected that there is a direct and indirect relationship with green business innovation, which consists of green input, green process, green products, and green marketing towards environmental sustainability in Umbulharjo District, Yogyakarta through knowledge, awareness, and concern of young coconut entrepreneurs (Cocos nucifera lin).

\section{METHODOLOGY}

This type of research used in this study is a quantitative approach presented with numbers. According to Sugiyono (2017), the quantitative research method is a research method based on the philosophy of positivism, used to research specific populations or samples, data collection using research instruments, and data analysis are quantitative or statistical, to test predetermined hypotheses. While the research variables used in this study are independent, namely: Green Input $\left(\mathrm{X}_{1}\right)$, Green Process $\left(\mathrm{X}_{2}\right)$, Green Product $\left(\mathrm{X}_{3}\right)$, and Green Marketing $\left(\mathrm{X}_{4}\right)$ and the dependent variable in this study are: Knowledge $\left(\mathrm{Y}_{1}\right)$, Awareness $\left(\mathrm{Y}_{2}\right)$, Concern $\left(\mathrm{Y}_{3}\right)$ and Variable $\mathrm{Z}$ : Environmental Sustainability.

\section{Population and Sample}

The population is a generalization area consisting of objects/subjects with certain qualities and characteristics determined by researchers to be studied and then draw their conclusions (Sugiyono, 2017). This study's population was 70 young coconut entrepreneurs taken randomly in the giwangan, warungboto, sorosutan, pendeyan, annual, muja-muju semaki villages. In the sampling carried out calculations using formula slovin $\mathrm{n}=\mathrm{N} /\left(1+\mathrm{N}(\mathrm{e})^{2}, \mathrm{n}=70 /\left(1+70(0.05)^{2}\right.\right.$. Based on the calculation results obtained, value $n=59.57$ rounded to 60 . As a result, the number of samples used in this study to 60 the entrepreneurial young coconut perpetrators. The sampling technique is used using purposive sampling. The data used in research are primary data and secondary data. Simultaneously, researchers collected data techniques used by researchers in observation, interview, questionnaire, and literature study.

\section{Analysis Method}

\section{Correlation Analysis}

Correlation analysis aims to determine the relationship between two or more variables (Prayitno, 20 09). In correlation calculation, use the correlation coefficient to assess rift relationships, the direction of the relationship, and whether or not those relationships using correlation analysis bivariate in this case, correlation product-moment (Pearson correlation).

\section{Test-Path Analysis ( Path Analysis )}

According to Sugiyono (2017), part of the path analysis model analyzes s causality a tar one variable to another variable. Meanwhile, according to Riduwan and Kuncoro (2014), path analysis is used to analyze the pattern of relationships between variables, which aims to determine the direct and indirect effect of a set of independent (exogenous) variables on the dependent (endogenous) variable.

\section{RESEARCH RESULT}

Based on the results of data processing obtained as follows:

\section{Bivariate Correlation Analysis}




\section{Relationship of Green Input, Green Process, Green Product and Green Marketing to Knowledge}

Table 1. Green Input, Green Process, Green Product Test Results and Green Marketing of Knowledge

\begin{tabular}{llc}
\hline & & Knowledge $\left(\mathbf{Y}_{1}\right)$ \\
\hline Green Input $\left(\mathrm{X}_{1}\right)$ & Pearson Correlation & .308 \\
\cline { 2 - 3 } & Sig. (2-tailed) & .017 \\
\cline { 2 - 3 } & $\mathrm{N}$ & 60 \\
\hline Green Process $\left(\mathrm{X}_{2}\right)$ & Pearson Correlation & $.338^{* *}$ \\
\cline { 2 - 3 } & Sig. (2-tailed) & .008 \\
\cline { 2 - 3 } & $\mathrm{N}$ & 60 \\
\hline Green Product $\left(\mathrm{X}_{3}\right)$ & Pearson Correlation & $.516^{* *}$ \\
\cline { 2 - 3 } & Sig. (2-tailed) & .004 \\
\cline { 2 - 3 } & $\mathrm{N}$ & 60 \\
\hline Green Marketing $\left(\mathrm{X}_{4}\right)$ & Pearson Correlation & $.527^{* *}$ \\
\cline { 2 - 3 } & Sig. (2-tailed) & .004 \\
\cline { 2 - 3 } & $\mathrm{N}$ & 60 \\
\hline
\end{tabular}

Source: Primary data processed, 2020

Green Input $\left(\mathbf{X}_{1}\right)$ has a positive correlation coefficient (person correlation) of 0.308 . Meanwhile, based on the significant value of Green Input $\left(\mathrm{X}_{1}\right)$ on Knowledge $\left(\mathrm{Y}_{1}\right)$, it has a value of $0.017<0.05$, which means that there is a positive relationship that weak between Green Input $\left(\mathrm{X}_{1}\right)$ to Knowledge $\left(\mathrm{Y}_{1}\right)$, suggesting hypothesis 1 proved. Meanwhile, Green Process $\left(\mathbf{X}_{2}\right)$ has a correlation coefficient value of 0.338 . From the significant value of the Green Process $\left(\mathrm{X}_{2}\right)$ on Knowledge $\left(\mathrm{Y}_{1}\right)$ of $0.008<0.05$. It shows a weak positive relationship between Green Process $\left(\mathrm{X}_{2}\right)$ and Knowledge ( $\left.\mathrm{Y}_{1}\right)$, so hypothesis 2 is proven. This study's results are in line with Utomo's research, Pratiwi (2016) confirms that the green process has an influence and relationship on financial and environmental sustainability. Furthermore, Green Product $\left(\mathbf{X}_{3}\right)$ has a correlation coefficient value of 0.516 . It shows the significant value of Green Product $\left(\mathrm{X}_{3}\right)$ on Knowledge $\left(\mathrm{Y}_{1}\right)$ of $0.004<0.05$. Meaning that there is a moderate positive relationship between Green Product $\left(\mathrm{X}_{3}\right)$ and sensible Knowledge $\left(\mathrm{Y}_{1}\right)$, so hypothesis 3 is proven. Priyanka's research results, Septizola (2019), demonstrate a significant effect of green products on brand image. Green Marketing $\left(\mathbf{X}_{4}\right)$ has a positive correlation coefficient (person correlation) of 0.527 , as can be seen from the significance value of Green Marketing $\left(\mathrm{X}_{4}\right)$ on Knowledge $\left(\mathrm{Y}_{1}\right)$ of $0.000<0.05$. It concludes that there is a moderate positive relationship between Green Marketing $\left(\mathrm{X}_{4}\right)$ and good Knowledge $\left(\mathrm{Y}_{1}\right)$, so hypothesis 4 is proven. The study results are following the research of Kusuma, Surya, Suhendra (2017) that green marketing influences purchasing decisions.

The Relationship between Green Input, Green Process, Green Product and Green Marketing on Awareness

Table 2 . Green Input, Green Process, Green Product Test Results and Green Marketing on Awareness

\begin{tabular}{llc}
\hline & & Consciousness (Y 2) \\
\hline Green Input $\left(\mathrm{X}_{1}\right)$ & Pearson Correlation & $.365^{\text {** }}$ \\
\cline { 2 - 3 } & Sig. (2-tailed) & .047 \\
\cline { 2 - 3 } & $\mathrm{N}$ & 60 \\
\hline
\end{tabular}




\begin{tabular}{|c|c|c|}
\hline \multirow[t]{3}{*}{ Green Process $\left(\mathrm{X}_{2}\right)$} & \multicolumn{2}{|l|}{ 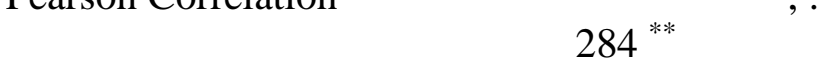 } \\
\hline & Sig. (2-tailed) & .039 \\
\hline & $\mathrm{N}$ & 60 \\
\hline \multirow[t]{3}{*}{ Green Product $\left(\mathrm{X}_{3}\right)$} & Pearson Correlation & $.810^{* *}$ \\
\hline & Sig. (2-tailed) & .003 \\
\hline & $\mathrm{N}$ & 60 \\
\hline \multirow[t]{3}{*}{ Green Marketing $\left(\mathrm{X}_{4}\right)$} & Pearson Correlation & $.537^{* *}$ \\
\hline & Sig. (2-tailed) & .004 \\
\hline & $\mathrm{N}$ & 60 \\
\hline
\end{tabular}

Source: Primary data processed, 2020

Green Input $\left(\mathbf{X}_{1}\right)$ has a correlation coefficient value of 0.365 . Meanwhile, based on the significant value of Green Input $\left(\mathrm{X}_{1}\right)$ on Consciousness $\left(\mathrm{Y}_{2}\right)$, it has a value of $0.047<$ 0.05 , then $\mathrm{Ha}$ is accepted, and $\mathrm{H} 0$ is rejected, which means a positive relationship that weak between Green Input $\left(\mathrm{X}_{1}\right)$ of the Consciousness $\left(\mathrm{Y}_{2}\right)$, than hypothesis 5 proven. It also means that the weaker Green Input $\left(\mathrm{X}_{1}\right)$ is creating a product, the level of awareness of entrepreneurs in Umbulharjo District, Yogyakarta is terrible. In line with Pebrianti study (2012) proves that environmental awareness has a relationship to the product organic. Meanwhile, Green Process $\left(\mathbf{X}_{2}\right)$ has a correlation coefficient value of 0.284. Meanwhile, based on the significant value of the Green process $\left(\mathrm{X}_{2}\right)$ on Awareness $\left(\mathrm{Y}_{2}\right)$, it has a value of $0.039<0.05$. It means that there is a positive relationship that weak between the Green Process $\left(\mathrm{X}_{2}\right)$ of the Consciousness $\left(\mathrm{Y}_{2}\right)$, then hypothesis 6 proved. This study's results are in line with Krisnanda's research, Nurcaya (2019), showing that environmental awareness has a positive and significant relationship to the process of making environmentally friendly products. Furthermore, Green Product $\left(\mathbf{X}_{3}\right)$ has a value of the correlation coefficient of 0.810 . Meanwhile, based on the significant value of Green product $\left(\mathrm{X}_{3}\right)$ on Awareness $\left(\mathrm{Y}_{2}\right)$, it has a value of $0.003<0.05$. It means that there is a positive relationship that is strong between Green Product $\left(\mathrm{X}_{3}\right)$ to Consciousness $\left(\mathrm{Y}_{2}\right)$, then hypothesis seven proved. The results of this study are proven by research by Lestari, Putri, Anindita, Laksmiari (2020), which shows that green products have a significant positive effect on green trust awareness. In comparison, the results of the calculation of Green Marketing $\left(\mathbf{X}_{4}\right)$ have a positive correlation coefficient value of 0.531 . Meanwhile, based on the significant amount of Green Marketing $\left(\mathrm{X}_{4}\right)$ on Awareness $\left(\mathrm{Y}_{2}\right)$, it has a value of $0.001<0.05$, then $\mathrm{Ha}$ is accepted, and $\mathrm{H} 0$ is rejected. It means that there is a positive relationship between Green Marketing $\left(\mathrm{X}_{3}\right)$ to Consciousness $\left(\mathrm{Y}_{2}\right)$, then hypothesis 8 proven. This study's results are following the results of research by Kusuma, Surya, Suhendra (2017) that green marketing has a positive and significant effect on purchasing decision awareness.

\section{Relationship between Green Input, Green Process, Green Product and Green Marketing on Concern}

Table 3 . Green Input, Green Process, Green Product Test Results and Green Marketing Concern

\begin{tabular}{llc}
\hline & & Concern $\left(\mathbf{Y}_{3}\right)$ \\
\hline Green Input $\left(\mathrm{X}_{1}\right)$ & Pearson Correlation & $.381^{* *}$ \\
\cline { 2 - 3 } & Sig. (2-tailed) & .003 \\
\cline { 2 - 3 } & $\mathrm{N}$ & 60 \\
\hline
\end{tabular}




\begin{tabular}{llc} 
Green Process $\left(\mathrm{X}_{2}\right)$ & Pearson Correlation & $.365^{* *}$ \\
\cline { 2 - 3 } & Sig. (2-tailed) & .004 \\
\cline { 2 - 3 } & $\mathrm{N}$ & 60 \\
\hline Green Product $\left(\mathrm{X}_{3}\right)$ & Pearson Correlation & $.532^{\text {** }}$ \\
\cline { 2 - 3 } & Sig. (2-tailed) & .000 \\
\cline { 2 - 3 } & $\mathrm{N}$ & 60 \\
\hline Green Marketing $\left(\mathrm{X}_{4}\right)$ & Pearson Correlation & $.448^{\text {** }}$ \\
\cline { 2 - 3 } & Sig. (2-tailed) & .000 \\
\cline { 2 - 3 } & $\mathrm{N}$ & 60 \\
\hline
\end{tabular}

Source: Primary data processed, 2020

Green Input $\left(\mathbf{X}_{\mathbf{1}}\right)$ has a correlation coefficient value of 0.381 . Meanwhile, based on the significant value of Green Input $\left(\mathrm{X}_{1}\right)$ on caring $\left(\mathrm{Y}_{3}\right)$, it has a value of $0.003<0,05$. It means a positive relationship that weak between Green Input $\left(\mathrm{X}_{1}\right)$ to Kepeduliaan $\left(\mathrm{Y}_{3}\right)$, suggesting hypothesis 9 proved. This study's results follow the research of Supandini, Pramudana (2017), where green input has a positive effect on environmental awareness. It means that the better the input (product composition and organic raw materials) the product uses, the higher it will influence the purchasing decision. Meanwhile, the results of the calculation of Green Process $\left(\mathbf{X}_{2}\right)$ have a correlation coefficient value of 0.365 . While based on the value of the significance of Green Process $\left(\mathrm{X}_{2}\right)$ of the Concern $\left(\mathrm{Y}_{3}\right)$ has a value of $0.004<0.05$, then there is a positive relationship that weak between the Green Process $\left(\mathrm{X}_{2}\right)$ of the Concern $\left(\mathrm{Y}_{3}\right)$, meaning hypothesis 10 proved. The results are consistent with research Betary (2020) demonstrate the green process Innovation has a positive and significant impact on the financial performance.

Green Product $\left(\mathbf{X}_{3}\right)$ has a positive correlation coefficient (person correlation) of 0.532 . That is a unidirectional relationship between Green Product $\left(\mathrm{X}_{3}\right)$ to Concern $\left(\mathrm{Y}_{3}\right)$ into the category medium. While based on the value of the significance of Green product $\left(\mathrm{X}_{3}\right)$ to Concern $\left(\mathrm{Y}_{3}\right)$ has a value of $0.000<0.05$, then there is a positive relationship that was between Green Product $\left(\mathrm{X}_{3}\right)$ to Concern $\left(\mathrm{Y}_{3}\right)$, meaning hypothesis 11 proved. It is consistent with research Priyanka, Septrizola (2019) that the variable green product has a relationship with the brand image. Besides, the research results, Lestari et al. (2020) proved that green products connect to environmental concern. The results of the calculation of Green Marketing ( $\left.\mathbf{X}_{4}\right)$ have a positive correlation coefficient (person correlation) of 0.448 . It means that the unidirectional relationship between Green Marketing $\left(\mathrm{X}_{4}\right)$ and Concern $\left(\mathrm{Y}_{3}\right)$ falls into the weak category. Meanwhile, based on the significant value of Green marketing $\left(\mathrm{X}_{4}\right)$ towards caring $\left(\mathrm{Y}_{3}\right)$, it has a value of $0.000<$ 0.05 , so there is a weak positive relationship between Green marketing $\left(\mathrm{X}_{4}\right)$ and Concern $\left(\mathrm{Y}_{3}\right)$, thus hypothesis 12 proven. This study's results are in line with Gunarso and Kusumawati (2017) research that environmentally friendly advertising can make consumers care and impact the environment.

\section{Direct Relationship of Green Input, Green Process, Green Products, and Green Marketing to Environmental Sustainability}

Table 4. Direct Test Results Green Input, Green Process, Green Product and Green Marketing for Environmental Sustainability

\begin{tabular}{llc}
\hline & & Environmental Sustainability (Z) \\
\hline Green Input $\left(\mathrm{X}_{1}\right)$ & Pearson Correlation & $.372^{* *}$ \\
\cline { 2 - 3 } & Sig. (2-tailed) & .003
\end{tabular}


Bahri ${ }^{1)}$, Ilmardani Rince Ramli ${ }^{2)}$, Widodo Prasetyo ${ }^{3)}$, Green Business Innovation, Knowledge, Awareness, Concern, Environmental Sustainability.

\begin{tabular}{llc}
\hline & $\mathrm{N}$ & 60 \\
\hline Green Process $\left(\mathrm{X}_{2}\right)$ & Pearson Correlation & $.278^{* *}$ \\
\cline { 2 - 3 } & Sig. (2-tailed) & .031 \\
\cline { 2 - 3 } & $\mathrm{N}$ & 60 \\
\hline Green Product $\left(\mathrm{X}_{3}\right)$ & Pearson Correlation & $.358^{* *}$ \\
\cline { 2 - 3 } & Sig. (2-tailed) & .003 \\
\cline { 2 - 3 } & $\mathrm{N}$ & 60 \\
\hline Green Marketing $\left(\mathrm{X}_{4}\right)$ & Pearson Correlation & $.413^{* *}$ \\
\cline { 2 - 3 } & Sig. (2-tailed) & .004 \\
\cline { 2 - 3 } & $\mathrm{N}$ & 60 \\
\hline
\end{tabular}

Source: Primary data processed, 2020

Green Input $\left(\mathbf{X}_{1}\right)$ has a positive correlation coefficient value of 0.372. Meanwhile, based on the significant value of Green Input $\left(\mathrm{X}_{1}\right)$ on Environmental Sustainability $(\mathrm{Z})$, it has a value of $0.003<0.05$. It means that there is a link directly to the positive and weak between Green Input $\left(\mathrm{X}_{1}\right)$ to flexitarian environment $(\mathrm{Z})$, pointing hypothesis 13 proven. The results of this study reinforced research Aman et al. (2012), which shows is a positive relationship between the intention of purchasing environmentally friendly products for environmental sustainability. Also, Hakim's (2010) research results prove that green input consisting of product composition, raw material characteristics, preservatives, and organic agricultural raw materials has a significant effect on purchasing decisions, which means that consumers start thinking about environmentally friendly products. The calculation results show that the Green Process $\left(\mathbf{X}_{2}\right)$ has a positive correlation coefficient value of 0.278. Meanwhile, based on the significant value of the Green Process $\left(\mathrm{X}_{2}\right)$ on Environmental Sustainability $(\mathrm{Z})$, it has a value of $0.031<0.05$. It means that there is a direct connection that is positive and weak between Green Process $\left(\mathrm{X}_{2}\right)$ for Environment Sustainability $(\mathrm{Z})$, pointing hypothesis 14 proven. This study's results align with Lukitaruna's (2017) research that Green Process Innovation has a positive and proven significant effect on company performance. The higher the application of the green process, the better the environmental sustainability.

Meanwhile, Green Product $\left(\mathbf{X}_{\mathbf{3}}\right)$ has a positive correlation coefficient value of 0.358 . Meanwhile, based on the significant value of Green Product $\left(\mathrm{X}_{3}\right)$ on Environmental Sustainability $(Z)$ has a value of $0.005<0.05$. It means that there is a direct relationship positive that weak between Green Product $\left(\mathrm{X}_{3}\right)$ against Environment Sustainability $(\mathrm{Z})$, pointing hypothesis 15 proven. The results are in line with research Ayu (2016) indicates that the variable green product has a relationship and a positive influence on purchasing decisions choose products based expediency and aware of the importance of preserving the environment. Efforts businesses to produce environmentally friendly products can affect consumers to have awareness, concern about friendly products, and environmental n (Saxena \& Khandelwal, 2012). Furthermore, the calculation result of Green Marketing $\left(\mathbf{X}_{4}\right)$ has a positive correlation coefficient value of 0.413 . Meanwhile, based on the significant value of Green Marketing $\left(\mathrm{X}_{4}\right)$ on Environmental Sustainability $(Z)$, it has a value of $0.001<0.05$. It means that there is a direct relationship positive that weak between Green Marketing $\left(\mathrm{X}_{4}\right)$ of the Environmental Sustainability $(\mathrm{Z})$, pointing hypothesis 16 proven. This study's results follow the research results by Brosdahl \& Carpenter (2010), which states that green marketing has a relationship with environmental sustainability. It indicates that the concept of environmentally friendly effects positive on the sustainability of the environment and concern for the environment positively influences the behavior of consumption of environmentally friendly products. Hakim's research results (2010) also show that green marketing is appropriate and can increase consumer purchasing decisions. By 
maintaining ecologically friendly attributes, aspects of promotion/advertising using the concept of green marketing can affect consumer purchases.

\section{Relationship of Knowledge, Awareness, and Concern for Environmental Sustainability}

Table 5. Knowledge, Awareness, and Concern Test Results Against Environment Sustainability

\begin{tabular}{llc}
\hline \multirow{2}{*}{ Knowledge } & & Environmental Sustainability \\
\cline { 2 - 3 } & Pearson Correlation & $.478^{* *}$ \\
\cline { 2 - 3 } & Sig. (2-tailed) & .000 \\
\cline { 2 - 3 } Awareness & $\mathrm{N}$ & 60 \\
\cline { 2 - 3 } & Pearson Correlation & $.371^{* *}$ \\
\cline { 2 - 3 } & Sig. (2-tailed) & .004 \\
\cline { 2 - 3 } Concern & $\mathrm{N}$ & 60 \\
\cline { 2 - 3 } & Pearson Correlation & $.358^{* *}$ \\
\cline { 2 - 3 } & Sig. (2-tailed) & .003 \\
\cline { 2 - 3 } & $\mathrm{N}$ & 60 \\
\hline
\end{tabular}

Source: Primary data processed, 2020

Knowledge has a positive correlation coefficient value of 0.478 . In contrast, based $n$ use-values, the significance of knowledge on environmental sustainability has a value of $0.000<0.05$. There is no relationship between the experience of ecological sustainability, pointing hypothesis 17 proven. Research results from Saputro, Rintayanti, Supeni (2016) demonstrate a relationship between environmental knowledge and attitudes to care for the environment. This study's results align with Rusniati's research, Rahmawati (2019), that experience affects green product purchasing decisions. Meanwhile, awareness has a positive correlation coefficient value of 0.371 . Furthermore, based on the significant value of environmental awareness, it has a value of $0.004<0.05$. It means that there is a weak positive direct relationship between the understanding of ecological sustainability. Following the research results by Paramita and Yasa (2015), which shows that the existence of higher environmental awareness can increase the purchase intention of environmentally friendly products. Research by Munawar, Haryanti, Miarsyah (2019) also proves that ecological knowledge and students' understanding have a relationship to the environment. While environmental concern has a positive correlation coefficient value of 0.369 . From significant value concern, to environmental sustainability value of $0.004<0.05$, the meaning positive relationship that is weak and significant correlates with concern towards environmental sustainability. Marita Ahdiyana's research (2011) proves the importance of environmental care for ecological sustainability. The study of Wulandari et al. (2018) also confirms that the community's caring behavior for the environment causes the environment around the Kandri tourist attraction to be organized.

\section{Result of Test-Path Analysis (Path Analysis)}

Indirect Relationship of Green Input, Green Process, Green Products, and Green Marketing to Environmental Sustainability (Z) through Knowledge 


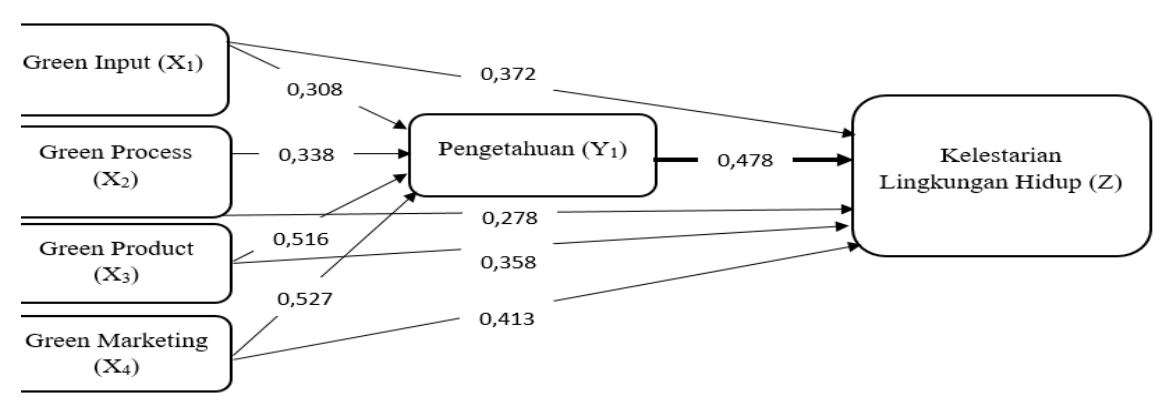

Figure 4.

Path Analysis of Green Input, Green Process, Green Products, and Green Marketing Against Sustainability lifestyle Environment Through Knowledge

The direct relationship of Green Input $\left(\mathbf{X}_{\mathbf{1}}\right)$ to Environmental Sustainability (Z) is 0.372. Meanwhile, the indirect relationship of Green Input $\left(\mathrm{X}_{1}\right)$ through Knowledge $\left(\mathrm{Y}_{1}\right)$ has a value of $0.308 \times 0.478=0.147$. The total relationship between Green input $\left(\mathrm{X}_{1}\right)$ and environmental sustainability $(\mathrm{Z})$ is obtained a value of $0.372+0.147=0.519$. Thus note that a direct connection Green Input $\left(\mathrm{X}_{1}\right)$ of 0.372 and an indirect relationship through Knowledge $\left(\mathrm{Y}_{1}\right)$ amounted to 0.147 , which means a greater immediate value indirectly, Knowledge $\left(\mathrm{Y}_{1}\right)$ is not successfully a liaison. These results indicate that Green Input does not have a relationship that is not directed towards sustainability. Extended circles Ungan Life through knowledge. Suparmoko (2002), in his book on "Economic Assessment: Natural Resources \& Environment (Concepts and Methods of Calculation)" describes the waste at the production level of security alone is not enough to get the "ecolabel," but the necessity of making material (input) environment destroyer.

While the calculation results obtained a direct relationship Green process $\left(\mathbf{X}_{2}\right)$ to Environmental Sustainability getting a value of 0.278. While the indirect relationship of Green Process $\left(\mathrm{X}_{2}\right)$ to Environmental Sustainability $(\mathrm{Z})$ through Knowledge $\left(\mathrm{Y}_{1}\right)$ with a value of $0.338 \times 0.478=0.161$. The total relationship between Green Process $\left(\mathrm{X}_{2}\right)$ and environmental sustainability $(Z)$ is $0.278+0.161=0.439$. So based on the results of the calculation of the direct relationship Green process $\left(\mathrm{X}_{2}\right)$ of 0.278 and the indirect relationship through Knowledge $\left(\mathrm{Y}_{1}\right)$ of 0.161 , which means that the direct value is greater than the indirect value, then Knowledge ( $\left.\mathrm{Y}_{1}\right)$ fails in becoming a link. These results indicate that Green Process does not have the relationship is not directly towards environmental sustainability through knowledge. This study's results are in line with the research of Rahayu, Abdillah, Mawardi (2017), which found it is important to change buying behavior with environmentally friendly products, with products whose production process can reduce side effects on the environment.

Furthermore, the calculation results obtained a direct relationship Green product $\left(\mathbf{X}_{3}\right)$ to Environmental Sustainability $(Z)$ of 0.358 . While the indirect relationship of Green product $\left(\mathrm{X}_{3}\right)$ to Environmental Sustainability $(\mathrm{Z})$ through Knowledge $\left(\mathrm{Y}_{1}\right)$ with a value of $0.516 \times 0.478=0.246$. The total relationship between Green product $\left(\mathrm{X}_{3}\right)$ and environmental sustainability $(Z)$ obtained a value of $0.358+0.246=0.604$. Based on the results of the calculation of the direct relationship of Green Product $\left(\mathrm{X}_{3}\right)$ of 0.358 and the indirect relationship through Knowledge $\left(\mathrm{Y}_{1}\right)$ of 0.246 , it means that the direct relationship has a greater value than the indirect relationship, so Knowledge $\left(\mathrm{Y}_{1}\right)$ fails in becoming the connecting variable. It is in line with Lestari's research results, et al. (2020), proving that green products have added value and are safe for health and 
environmental sustainability. Furthermore, Kusumawati (2015) also proves the green product influences consumers' importance to buy environmentally friendly products to minimize the environmental impact of products used. While the results of the calculation of the direct relationship of Green Marketing $\left(\mathbf{X}_{4}\right)$ to environmental sustainability $(\mathrm{Z})$ is 0.413 . While the indirect relationship of Green marketing $\left(\mathrm{X}_{4}\right)$ to Environmental Sustainability $(\mathrm{Z})$ through Knowledge $\left(\mathrm{Y}_{1}\right)$ with a value of $0.527 \mathrm{x} 0.478$ $=0.251$. The total relationship between Green marketing $\left(\mathrm{X}_{4}\right)$ and environmental sustainability $(Z)$ has a value of $0.413+0.251=0.664$. Based on the results of the calculation of the direct relationship of Green Marketing $\left(\mathrm{X}_{4}\right)$ of 0.413 and the indirect relationship through Knowledge $\left(\mathrm{Y}_{1}\right)$ of 0.251 , meaning that the direct relationship has a greater value than the indirect relationship, then Knowledge $\left(\mathrm{Y}_{1}\right)$ does not succeed in becoming a connecting variable. The green marketing $\left(\mathrm{X}_{4}\right)$ of the Environmental Sustainability (Z). These results indicate that green marketing has no indirect relationship to environmental sustainability through knowledge. The results of this study support the theory presented by Agustin (2015), where green marketing is a product marketing process that is assumed to be safe for the environment. Setiyaningrum, Madiawati (2015) also explains that ecolabels, eco brands, and environmental-themed advertisements of green marketing tools can increase consumer knowledge about environmentally friendly products.

\section{Indirect Relationship of Green Input, Green Process, Green Product and Green Marketing $\left(\mathbf{X}_{4}\right)$ Toward Environmental Sustainability through Awareness}

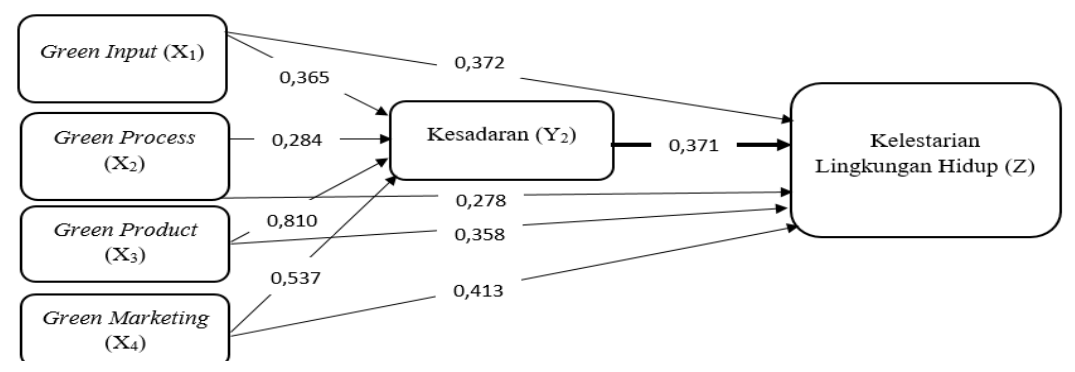

Figure 5.

Analysis of Green Input Pathways, Green Processes, Green Products and Green Marketing $\left(\mathrm{X}_{4}\right)$ on Environmental Sustainability through Awareness

Analysis of the direct relationship of Green Input $\left(\mathbf{X}_{\mathbf{1}}\right)$ to Environmental Sustainability $(\mathrm{Z})$ is 0.372. Meanwhile, the indirect relationship of Green Input $\left(\mathrm{X}_{1}\right)$ through Awareness $\left(\mathrm{Y}_{2}\right)$ obtained a value of $0.365 \times 0.371=0.135$. The total relationship between Green input $\left(\mathrm{X}_{1}\right)$ and environmental sustainability $(\mathrm{Z})$ has a value of $0.372+$ $0.135=0.507$. So it is known that the direct relationship of Green Input $\left(\mathrm{X}_{1}\right)$ is 0.372 and the indirect relationship through Consciousness $\left(\mathrm{Y}_{2}\right)$ is 0.135 , which means that the direct value is greater than the indirect value, so Consciousness $\left(\mathrm{Y}_{2}\right)$ does not succeed to be the connecting variable. These results indicate that Green Input did not have a relationship that does not align with the theory presented by Muslim and Indriani (2014). The pattern of human life began to shift with increasing awareness of the Environment is evidenced by the demand for entrepreneurs to undertake environmental responsibility (environmental responsibility) based on environmental sustainability. Furthermore, the value of the Green Process $\left(\mathbf{X}_{2}\right)$ to Environmental Sustainability $(Z)$ is 0.278. Meanwhile, the indirect relationship between Green Process $\left(\mathrm{X}_{2}\right)$ and Consciousness $\left(\mathrm{Y}_{2}\right)$, the value is $0.284 \times 0.371=0.105$. The total relationship between the Green Process $\left(\mathrm{X}_{2}\right)$ and environmental sustainability $(\mathrm{Z})$ is $0.278+0.105=0.383$. 
So it is known that the direct relationship of Green Process $\left(\mathrm{X}_{2}\right)$ is 0.278 , and the indirect relationship through Consciousness $\left(\mathrm{Y}_{2}\right)$ is 0.105 , which means that the direct value is greater than the indirect value. Hence, Consciousness $\left(\mathrm{Y}_{2}\right)$ fails in becoming the connecting variable. These results indicate that the Green Process has no indirect relationship to Environmental Sustainability through Awareness.

In line with those expressed usage et al. (2015), the green product is a product that is environmentally designed and processed in a manner to reduce the effects that can pollute the environment, both in production, distribution, and consumption. $\mathrm{H}$ acyl research Paramita, Yasa (2015) proves that environmental awareness can improve consumers' purchasing intentions to the p rock environmentally friendly. Also, the value of the direct relationship of Green Product (X3) to Environmental Sustainability $(Z)$ was obtained of 0.358 . Meanwhile, the indirect relationship of Green Product $\left(\mathrm{X}_{3}\right)$ through Awareness $\left(\mathrm{Y}_{2}\right)$ obtained a value of $0.810 \mathrm{X} 0.371=0.300$. The total relationship between Green Product $\left(\mathrm{X}_{3}\right)$ and environmental sustainability $(\mathrm{Z})$ has a value of $0.358+0.300=0.658$. The known direct relationship Green Product $\left(\mathrm{X}_{3}\right)$ is equal to 0.358 and indirect relations through Consciousness $\left(\mathrm{Y}_{2}\right)$ of 0.300 , which means immediate value greater than the indirect value. Rusniati and Rahmawati's research results (2019) reveal that green products are created to reduce the excessive use of natural resources during the production process and minimize environmental impacts. Meanwhile, the direct relationship value of Green Marketing $\left(\mathbf{X}_{4}\right)$ to Environmental Sustainability $(\mathrm{Z})$ is 0.413 . While the indirect relationship of Green Marketing $\left(\mathrm{X}_{4}\right)$ through Awareness $\left(\mathrm{Y}_{2}\right)$ obtained a value of $0.537 \mathrm{X} 0.371=0.199$. The total relationship of Green Marketing $\left(\mathrm{X}_{4}\right)$ to environmental sustainability $(\mathrm{Z})$ has a value of $0.413+0.199=0.612$. So it is known that the direct relationship of Green Marketing $\left(\mathrm{X}_{4}\right)$ is 0.413 , and the indirect relationship through Consciousness $\left(\mathrm{Y}_{2}\right)$ is 0.199 , which means that the direct value is greater than the indirect value. Hence, Consciousness $\left(\mathrm{Y}_{2}\right)$ fails in becoming the connecting variable. These results indicate that Green Marketing does not have a relationship that is not inversely proportional to Supandini's research results, Pramudana (2017), where environmental awareness has significantly succeeded in mediating green marketing towards purchasing intentions for environmentally friendly products.

\section{Indirect Relationship of Green Input, Green Process, Green Products, and Green Marketing to Environmental Sustainability (Z) through Caring}

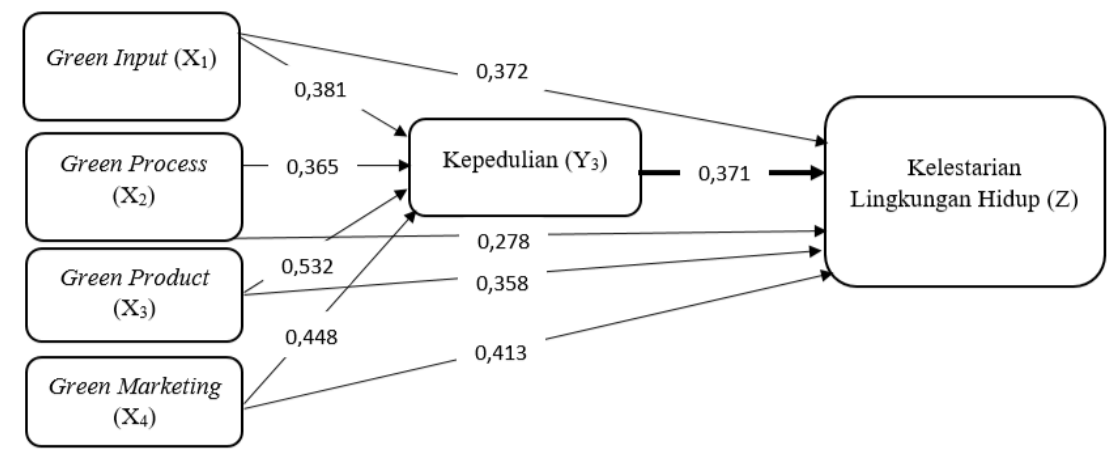

Figure 6.

Path Analysis of Green Input, Green Process, Green Products, and Green Marketing Toward Sustainability Lingkung 's Life Through Concern

The data analysis results showed that the value of the direct relationship of Green Input $\left(\mathbf{X}_{1}\right)$ to Environmental Sustainability (Z) was 0.372 . While the indirect 
relationship of Green Input $\left(\mathrm{X}_{1}\right)$ through caring $\left(\mathrm{Y}_{3}\right)$, the value is $0.381 \times 0.371=0.141$. The total relationship between Green input $\left(\mathrm{X}_{1}\right)$ and environmental sustainability $(\mathrm{Z})$ has a value of $0.372+0.141=0.513$. So it is known that the direct relationship of Green Input $\left(\mathrm{X}_{1}\right)$ is 0.372 , and the indirect relationship through Concern $\left(\mathrm{Y}_{3}\right)$ is 0.141 . It means that the direct value is greater than the indirect value, so Concern $\left(\mathrm{Y}_{3}\right)$ fails in becoming the connecting variable between Green Input. On Environmental Conservation. These results indicate that Green Input has no indirect relationship to Environmental Sustainability through Caring. In line with the research of Aman et al. (2012) show that there is a strong positive relationship between concern and intention to purchase environmentally friendly products. Meanwhile, the direct relationship between Green Process $\left(\mathbf{X}_{2}\right)$ and Environmental Sustainability $(Z)$ has a value of 0.278 . Meanwhile, the indirect relationship of Green Process $\left(\mathrm{X}_{2}\right)$ through caring $\left(\mathrm{Y}_{3}\right)$ obtained a value of $0.365 \times 0.371=0.135$. The total relationship between Green Process $\left(\mathrm{X}_{2}\right)$ and Environmental Sustainability $(\mathrm{Z})$ is $0.278+0.135=0.413$. So it is known that the direct relationship between Green Process $\left(\mathrm{X}_{2}\right)$ is 0.278 and the indirect relationship through Caring $\left(\mathrm{Y}_{3}\right)$ is equal to 0.135 , which means the direct value is greater than the indirect value, so Concern $\left(\mathrm{Y}_{3}\right)$ fails in becoming the connecting variable. These results indicate that the Green Process has no indirect relationship to Environmental Sustainability through Caring. It means that entrepreneurs still pay attention to environmental sustainability in the process of making products. Awareness of the Environment has a close relationship with the Environment and processes in manufacturing green products (Usadi et al. 2015). Entrepreneurs need to care and know about the process of making green products based on the Environment.

Furthermore, data processing results obtained a direct relationship value of Green Product $\left(\mathbf{X}_{3}\right)$ to Environmental Sustainability $(\mathrm{Z})$ of 0.358 . While the indirect relationship of Green Product $\left(\mathrm{X}_{3}\right)$ through caring $\left(\mathrm{Y}_{3}\right)$, the value is $0.532 \times 0.371=$ 0.197. The total relationship between Green product $\left(\mathrm{X}_{3}\right)$ and Environmental Sustainability $(Z)$ has a value of $0.358+0.197=0.555$. So it is known that the direct relationship of Green Product $\left(\mathrm{X}_{3}\right)$ is 0.358 , and the indirect relationship through Caring $\left(\mathrm{Y}_{3}\right)$ is 0.197 , which means that the direct value is greater than the indirect value. Hence, Concern $\left(\mathrm{Y}_{3}\right)$ fails in becoming the connecting variable. These results indicate that Green Product has no indirect relationship to Environmental Sustainability through Caring. The results of the study, Aman et al. (2012), Kanchanapibul et al. (2013), Usadi et al. (2015) proved that environmental sustainability influenced by the purchase of green products, where the more green products are sold, the environmental sustainability will be maintained. Meanwhile, the direct relationship between Green Marketing $\left(\mathbf{X}_{4}\right)$ and Environmental Sustainability $(Z)$ has a value of 0.413 . While the indirect relationship of Green Marketing $\left(\mathrm{X}_{4}\right)$ through caring $\left(\mathrm{Y}_{3}\right)$, the value is $0.448 \mathrm{X}$ $0.371=0.166$. The total relationship between Green Marketing $\left(\mathrm{X}_{4}\right)$ and Environmental Sustainability $(\mathrm{Z})$ has a value of $0.413+0.166=0.579$. So it is known that the direct relationship of Green Marketing $\left(\mathrm{X}_{4}\right)$ is 0.413 and the indirect relationship through Caring $\left(\mathrm{Y}_{3}\right)$ is 0.166 , which means that the direct value is greater than the indirect value, so Concern $\left(\mathrm{Y}_{3}\right)$ fails in becoming the connecting variable. These results indicate that green marketing does not have an indirect relationship to environmental sustainability through caring. The results of this study support the theory presented by Situmorang (2012) that green marketing not only offers environmentally-friendly products but includes the production process and product distribution using environmentally friendly raw materials. Setiawan's research results, Rabuani (2019), proved that it does not directly advertise through brand decisions and has exhibited significant influence on purchasing decisions. 
Based on the results of the research discussion has been done, it can be used as conclusions in this study, as follows:

\section{Relationship of Green Input, Green Process, Green Product and Green Marketing to Knowledge}

Green Input has a correlation coefficient value of 0.308 , and based on the significance value Green Input has a weak positive relationship to Knowledge. Meanwhile, the Green Process has a correlation coefficient value of 0.338 . Based on the significant amount, the Green Process has a weak positive relationship to Knowledge. Furthermore, Green Product has a correlation coefficient value of 0.516 , and seen from the significance value Green Product has a moderate positive relationship to experience. While Green Marketing has a correlation coefficient value of 0.527 and is seen from the significance value, Green Marketing has an average positive relationship to Knowledge.

\section{The Relationship between Green Input, Green Process, Green Product and Green Marketing on Awareness}

Green Input has a correlation coefficient value of 0.365 , and seen from the significance value Green Input has a weak positive relationship to awareness. Green Process has the value of the coefficient of correlation of 0.284 , and views based on the Green Process's significance have a positive correlation is weak against Consciousness. While Green Product has a value of the correlation coefficient of 0.810 , and the views of the amount of the significance of Green product have a strong positive relationship between Kesadara n. Meanwhile, Green Marketing has a correlation coefficient value of 0.531 , and seen from the significance value Green Marketing has a moderate positive relationship with awareness.

\section{Relationship between Green Input, Green Process, Green Product and Green Marketing on Concern}

Green Input has a correlation coefficient value of 0.381 , and based on the significance value Green Input has a weak positive relationship to care. Green Process has a matter of the correlation coefficient of 0.365. Based on the value of the Green Process's significance has a weak positive relationship towards to concern. Furthermore, Green Product has a correlation coefficient value of 0.532 based on the significance value, and Green Product has a moderate positive relationship with concern. Moreover, Green Marketing has a matter of the correlation coefficient of 0.448 . Based on the value of the significance of Green Marketing has a weak positive relationship with concern.

\section{Relationship of Knowledge, Awareness, and Concern for Environmental Sustainability}

Knowledge has a correlation coefficient value of 0.478 and is based on the significance value, and knowledge has a weak positive relationship to Environmental Sustainability. Meanwhile, awareness has a correlation coefficient value of 0.371 and is based on the significance value, and attention has a fragile positive relationship to Environmental Sustainability. Furthermore, concern has a correlation coefficient value of 0.369 and is based on the significance value, and the matter has a connection to environmental conservation.

Direct Relationship of Green Input, Green Process, Green Products, and Green Marketing to Environmental Sustainability 
Green Input has a correlation coefficient value of 0.372 , and based on the significance value Green Input has a direct relationship to Environmental Sustainability. The Green Process has a correlation coefficient value of 0.278 and is based on the Green Process significance value, and there is a positive and weak direct relationship to Environmental Sustainability. While Green Product has a correlation coefficient value of 0.358 and based on the significance value, Green Product has a positive and weak direct relationship to Environmental Sustainability. Furthermore, Green Marketing has a matter of the correlation coefficient of 0.413 , and based on the significance of Green Marketing has a direct relationship positive and weak towards environmental sustainability.

Indirect Relationship of Green Input, Green Process, Green Products, and Green Marketing to Environmental Sustainability through Knowledge

1. Direct link Green Input to the environment sustainability shows that green input may indirectly relate to environmental sustainability through knowledge.

2. Direct link Green process towards environmental sustainability shows that the green process may be related indirectly to environmental sustainability through knowledge.

3. The direct link Green product to environment sustainability shows that green products do not have a relationship indirectly to environmental sustainability through knowledge.

4. Direct link Green Marketing sustainability of the environment shows that the green marketing be related indirectly to the environmental sustainability through knowledge.

Indirect Relationship of Green Input, Green Process, Green Products and Green Marketing towards Environmental Sustainability through Awareness

1. Direct link Green Input restricted to environmental sustainability shows that green input be related indirectly to environmental sustainability through variable consciousness.

2. The direct link Green Process towards environmental sustainability shows that green process be related indirectly to ecological sustainability through awareness.

3. Direct link Green Product for environment sustainability shows that green products be related indirectly to environmental sustainability through awareness.

4. Direct link Green Marketing towards environmental sustainability shows that green marketing be related indirectly to ecological sustainability through awareness.

Indirect Relationship of Green Input, Green Process, Green Product and Green Marketing to Environmental Sustainability through Caring

1. Green Input to environmental sustainability's direct relationship shows that green input does not directly relate to environmental sustainability through caring.

2. The direct link green process towards environmental sustainability shows that green process be related indirectly to ecological sustainability through awareness.

3. Direct link green product of the environmental sustainability shows that green products be related indirectly to environmental sustainability through awareness.

4. Direct link green marketing towards environmental sustainability shows that green marketing be related indirectly to ecological sustainability through awareness.

\section{SUGGESTIONS}

From the results of this study, the researchers provide the following suggestions:

1. It is hoped that the government will provide land and TPS for waste disposal so that people do not throw garbage in illegal places and provide training on how to 
process coconut waste into high-selling business products in collaboration with local universities.

2. It is hoped that young coconut entrepreneurs in each urban village will have awareness and concern in protecting environmental sustainability by not piling up their waste by the roadside not to spoil the view and disturb others' health.

3. For future researchers, it is expected to add to the research variables and not only discuss young coconut actors but other entrepreneurs.

\section{REFERENCES}

Agustin, RD (2015). The influence of green marketing on purchase intention and its impact on purchasing decisions (Survey on non-member consumers of Tupperware in Malang). Journal of Business Administration, 22 (2). 1-10.

Aman, AL, Harun, A., and Hussein, Z. (2012). The Influence of Environmental Knowledge and Concern on Green Purchase Intention the Role of Attitude as a Mediating Variable. British Journal of Arts and Social Sciences, 7 (2), 145-167.

Azmi, F., \& Elfayetti, E. (2017). Analysis of Students' Environmental Care Attitudes through the Adiwiyata Program at SMA Negeri 1 Medan. Journal of Geography, 9 (2), 125-132.

Aulia, FZ (2015). The influence of company characteristics, environmental performance, and media coverage on environmental disclosure. Dissertation. Semarang State University.

Betary, D. (2020). Green Process Innovation and Financial Performance. Essay. Surabaya: Faculty of Economics and Business, Airlangga University.

Brosdahl, DJC, and JM Carpenter. 2010. Green Marketing of the environmental impacts of Textile and Apparel Production, Concern for the Environment, and Environmentally Friendly Consumption Behavior. JTATM , 6 (4): 1-9

Fitriani, LK (2017). Analysis of Green Innovation Impact on Competitive Advantage of Products and Marketing Performance (Empirical Study on SMEs of Ciwaringin Batik Cirebon Regency). Journal of Management and Business Review, 12 (2). 105-125.

Fitriyah, H., Tjahjadi, B., \& Soewarno, N. (2020). The Role of Green Product Innovation in Mediating the Influence of Corporate Social Responsibility on Creative Industry Business Performance. Journal of Accounting Science, 4 (1), $12-28$.

Gunarso, A., \& Kusumawati, A. (2017). The Effect of Green Advertising, Eco Brand, and Green Trust on Purchasing Decisions (Survey on Philips LED Light Consumers in RW 12, Merjosari Village, Lowokwaru District, Malang City). Journal of Business Administration, 49 (1), 169-178.

Hafizah, IN (2018). Environmental Preservation in Islamic Education Perspective. Doctoral dissertation, Muhammadiyah University of Purwokerto.

Judge. (, 2010). Analysis of the Effect of the Green Marketing Concept on Product Purchasing Decisions at Serambi Botani, Botani Square. Thesis. Bogor: Bogor Agricultural University.

Hasibuan, Malayu. ( 2012 ) . HR Management. Revised Edition, Thirteenth Printing. Jakarta: Earth Literacy. 
Karim, A. (2018). Developing awareness of preserving the Environment based on humanism in religious education. Education: Journal of Islamic Education Research, 12 (2), 309-330.

Kusuma, EI, Surya, D., \& Suhendra, I. (2017). The Effect of Green Marketing Strategy and Environmental Knowledge on Purchasing Decisions through Purchase Intention as an Intervening Variable (Study on Tupperware members in Rangkasbitung City). Journal of Business Research and Management Tirtayasa, 1 (1). 33-50.

Krisnanda, Ngurah Bagus Jaya., \& Nurcahya, I Nyoman. (, 2019). The Influence of Environmental Awareness on Consumer Perceptions and Intention to Buy Philips LED Products in Denpasar City. E-Journal of Management, 8 (2). 80728104.

Lestari, ER, Putri, HK, Anindita, C., \& Laksmiari, MB (2020). The Influence of Green Products ( Green Drinks), Green Advertising, and Environmental Concern for Green Trust and Implications for Purchase Intention. Journal of Agricultural Technology, 21 (1), 1-10.

Lukitaruna, Refarandira. (, 2017). The Influence of Green Product Innovation and Green Process Innovation on Company Performance (Empirical Study: In Manufacturing Companies Listed on the Indonesia Stock Exchange 2014-2016 Period). Essay. Surabaya: Airlangga University.

Muttaqien, K., Sugiarto, S., \& Sarifudin, S. (2019). Efforts to increase public awareness of environmental health through the waste bank program. Indonesian Journal of Adult and Community Education, 1 (1), 6-10.

Muslim, E., \& Indriani, DR (2014). Analysis of the effect of ecolabel on consumer awareness of buying green products. Journal of Technology Management, 13 (1), 86-100.

Paramita, ND, \& Yasa, NNK (2015). Attitudes in mediating the relationship between environmental awareness and purchase intention of environmentally-friendly cosmetic products. Journal of Management and Entrepreneurship, 17 (2), 187195.

Pebrianti, W. (2012). Analysis of the Effect of Environmental Awareness and Premium Prices on Purchase Intention of Green Products in Pontianak. Journal of Economics, Business, and Entrepreneurship, Untan, 3 (1), 69-84.

Usadi, Made Pradnyan., Giantari., \& Wardana. (, 2015). The Role of Concern for the Environment in Mediating the Effect of Knowledge of the Environment on Purchasing Intention of Green Products (Study on Samsung Brand LED TV Products in Denpasar City). Management E-Journal, 4 (1). 39-58.

Prayitno, Duwi. (, 2009). SPSS for Correlation, Regression, and Multivariate Analysis. Yogyakarta: Gava Media.

Priyanka, DF, Septizola. (, 2019). Effect of Green Product and Green Promotion on Brand Image of PT Suzuki Indomobil in Padang City. Journal of Ecogen, 2 (2), 165-168.

Rahmawati, NI (2018). The Splendor of "the Greening of Management" in Indonesia: Journal of Social and Humanities, 2 (1), 41-52.

Rahayu, LMP, Abdillah, Y., \& Mawardi, MK (2017). The Effect of Green Marketing on Consumer Purchase Decisions (Survey on The Body Shop's Consumers in Indonesia and Malaysia). Journal of Business Administration, 43 (1), 121-131.

Rini, AS, Sukaatmadja, IPG, \& Giantari, IGAKG (2017). The influence of environmental Knowledge and environmental concern on attitudes and purchase intentions of green products "the Body Shop" in Denpasar. E-Journal of Economics and Business, Udayana University, 6 (1), 137-166. 
Riduwan ., \& Kuncoro. (2014). How to Use and Use Path Analysis . 6th printing. Bandung: Alfabeta.

Saputro, D., Rintayati, P., \& Supeni, S. (2016). The Relationship between Environmental Knowledge, Socio-Economic Level, and Education Level Towards Environmental Care Attitudes ( For Housewives in Jati Agung Village, Ambarawa District, Pringsewu Regency, Lampung in 2015 and as a Learning Substance in Class XI IPS Geography in SMA). GeoEco, 2 (2). 128-136.

Saxena, RP \& Khandelwal, PK (2012). Greening of industries for sustainable growth: An exploratory study on durable, non-durable, and services industries. International Journal of Social Economics, 38 (9), 551-586.

Setiawan, B., \& Rabuani, CC (2019). The Effect of Advertising and Endorsers on Brand Awareness and Its Impact on Purchasing Decisions. Research , 1 (1), 001-015.

Situmorang, JR (2012). Green Marketing is Increasingly a Need in the Business World. Journal of Business Administration, 7 (2). 35-46.

Sugiyono. (, 2017). Quantitative Research Methods, Qualitative, and R \& D. Bandung: Alfabeta.

Supandini, PA, \& Pramudana, KAS (2017). The Role of Concern for the Environment in Mediating the Effect of Green Marketing on the Intention of Purchasing Green Products. E-Journal of Management of Udayana University, 6 (7). 39063933.

Suparmoko. (, 2002). Economic Assessment: Natural Resources \& Environment (Concept and Method of Calculation). Publisher: BPFE.

Utami, RD, Gunarsih, T., \& Aryanti, T. (2014). The Influence of Knowledge, Concern, and Attitudes on the Environment on Purchasing Interest in Green Products. Media Trend, 9 (2). 151-161.

Utomo, MN, \& Pratiwi, SR (2016). Analysis of Green Business Application on SME Performance in Tarakan City. The University of Borneo Tarakan, 1- 7.

Wulandari, AD, Arifien, M., \& Suharini, E. (2018). Community Environmental Care Behavior in Management of Kandri Tourism Village, Gunungpati District. Edu Geography, 6 (3), 170-176.

Yaumi, M., 2014. Character Education: Foundation, Pillars, and Implementation. Jakarta: Perdana Media Group

Zaraswati, C., Sumarwan, U., \& Wijayanto, H. (2017). Marketing Strategy of Commercial Health Insurance Company. Indonesian Journal of Business and Entrepreneurship (IJBE), 3 (1), 1-10. 